\title{
The state of South African media: a space to contest democracy
}

\author{
Herman Wasserman
}

Published online: 2 July 2020

(C) The Editors of the Journal 2020

\begin{abstract}
The South African media has played an important political and social role in the two and a half decades since the end of apartheid. Benefiting from strong Constitutional guarantees of freedom of expression and a vibrant civil society, the South African media have contributed to a culture of democratic debate while playing a watchdog role to keep political power to account through investigative reporting into corruption and malfeasance. Despite these positive developments in the emerging democracy, the role of the South African media has also been strongly contested. The media itself bears the characteristics of the continuing severe socioeconomic inequalities in the rest of South African society, and especially the print media have been accused of serving mostly an elite. Normative self-regulatory policy in the country has also been contested and has gone through several revisions in order to be more responsive to the needs of the developing South African society. This article provides an overview of the major issues and debates pertaining to the normative values and ethical practices of the South African media and assesses the extent to which the media emerged as a space where democracy itself was contested.
\end{abstract}

Keywords Democracy $\cdot$ Media $\cdot$ South Africa $\cdot$ Normative frameworks · Transition

\section{Introduction}

In order to consider the current state of the South African media, it is necessary to locate it within a set of historical developments that go back at least 25 years to 1994 , when the country transitioned from an authoritarian political system characterized

Prof. H. Wasserman $(\bowtie)$

Centre for Film and Media Studies, University of Cape Town, AC Jordan Building, Upper Campus,

Rondebosch, South Africa

E-Mail: herman.wasserman@uct.ac.za 
by minority, racist rule to a democracy. Although formal democracy has been in place for more than two decades, the country can in many ways still be considered a transitional society, as many of the socio-economic legacies of the apartheid era still have a clear bearing on contemporary society, and the media's role within it. Many of these legacies also precede the apartheid era, and an even wider historical view to the colonial era would therefore be more beneficial to evaluate debates about normative policies for the media in post-apartheid society, and understand audience attitudes towards the contemporary media.

Viewing the South African media as one located within a transitional context also invites comparative perspectives. The end of apartheid and the advent of democracy in 1994 can be seen as part of a wider set of global events in the 1990s that led to the collapse of authoritarian regimes and the rise of more democratic political dispensations. The 'wave of democracy' that swept the world in the 1990s and included South Africa have reverberated in global political life for the past decades (cf. Voltmer 2013, p. 1). The transition to democracy in South Africa came shortly after the fall of the Berlin Wall, and more recent examples of democratization in places like Tunisia, Syria and Egypt have been compared to those earlier transitions (cf. Voltmer 2013 , p. 1), even as they have often resulted in a return to more authoritarian forms of government. These transitions have given rise to a body of literature referred to variously as "democratization theory", "transitology" or the "transition paradigm". Democratization, as a "highly dramatic, often traumatic, experience that turns whole societies upside down" (Voltmer 2019, p. 7) also frequently involves conflict, and as such the link between media, conflict and democratization has become an important sub-field of democratization scholarship (cf. Voltmer et al. 2019). South Africa has seen, and continues to see, its share of these democratization conflicts, and the media has often been central to the discursive contestations around rights, responsibilities and benefits of the democratization process.

Although the transition paradigm has been widely used as a lens through which to view political shifts from authoritarianism to democracy around the world, it has shown to have some important shortcomings. The most important criticism of the democratization scholarship has been its implied "teleological thinking" which suggests a "unidirectional process from a non-democratic system towards a representative and accountable government", such as that democratization follows a specific set of identifiable stages ending in liberal democracy of the kind found in established democracies (Voltmer 2019, p. 6). The current rise of global populism have led to democratic regressions not only in Africa but in many other parts of the world (including in the established democracies of Europe and the United States). On the African continent, democratization has often taken the form of cycles which includes democratic regression and lapses to authoritarianism, or the combination of different forms of government resulting in a hybrid system of governance, rather than a linear path leading to the inevitable end goal of a Western-style liberal democracy. The result has often been hybrid regimes where democratic institutions and procedures combined with continued authoritarian tendencies in government (cf. Vladisavljević 2015), neo-patrimonial networks (cf. Stremlau and Iazzolino 2017) and a continuity of elites in powerful positions (cf. Sparks 2009). This situation also pertains to South Africa. While democratization theory remains a useful point of departure to 
consider major social changes and the media's role within them, a teleological view of media and democratization should therefore be avoided.

This article will focus on debates around media ethics in South Africa in the post-apartheid era, both in terms of the substantive, normative aspects to do with the media's role in society as well as the more procedural aspects of regulation, codification and adjudication of media ethics. It is argued that normative media ethics is a good lens through which to view debates about the media's role in an emerging democracy in general, as these debates go to the core of societal expectations of the limits to governmental power, the nature of participatory citizenship and the relationship between civil society, corporate interests and the state. As will be shown in the article, the debates about the media's role in society and the government's relationship to the media in South Africa relate to wider discussions about the nature of post-apartheid democracy, citizenship and socio-economic conditions. First, a short overview of the current media system will be given, followed by a brief historical overview to locate the post-apartheid South African media, and especially the impact of the democratic transition on the media landscape, against a broader historical background. This will be followed by a discussion focusing on the debates around the normative policy and self-regulation that can be seen as an indication of the contestations marking the post-apartheid media sphere, before drawing some brief conclusions.

\section{The South African media landscape}

The current South African media landscape can be categorized according to three tiers: public media, commercial media and community media. Recognizing that the South African media serves a broad, diverse and socio-economically highly unequal population, the rationale for the public and community media is to provide important counterbalances to the commercial media. The latter-especially the print media, with the exception of mass-market tabloid papers - serve largely elite audiences and are therefore more likely to produce a news agenda that is of interest to those who can afford access to commercial media, or who are attractive consumers for advertisers. Community media are seen to provide important opportunities for underserved sections of the public, such as those in small towns in rural areas, to receive information of interest to them that might not reach the agenda of big commercial media. Broadcast licences are awarded to community radio stations that can demonstrate that they serve a particular geographic community or community of interest, such as religious groups.

The Media Development and Diversity Agency (MDDA) was established in 2003 as a partnership between the South African Government and major commercial media entities to provide a fund that could support community print and broadcast media aimed at historically disadvantaged communities, historically diminished language and cultural groups and inadequately served communities (cf. MDDA 2020). The objective of this agency is therefore to create more plurality in the highly concentrated and conglomerated South African media market. The Agency is funded 
by a levy on licensed broadcast and print media, but in recent years there have been increasing criticism that the Agency has mismanaged its funds.

The public media consists of the South African Broadcasting Corporation (SABC), which has transformed from a state broadcaster under apartheid to a public entity which reports to parliament. Under apartheid, the SABC provided a platform for government propaganda and was organized according the logic of apartheid, with different radio and television channels for different ethnic groups. In the postapartheid era, the SABC has as its mandate to serve the broad public interest, although it has also been mired in problems with corruption, mismanagement and political interference in its editorial agendas.

Radio and television remain, however, the most widely accessed forms of media in the country, and the SABC continues to play an influential role in this regard. SABC television news tops the list of offline news consumption platforms, with its commercial free-to-air rival eNCA in second place. These are followed by radio news, where the biggest audience share is taken by those channels broadcasting in indigenous languages (cf. Roper et al. 2019, p. 9). Both in terms of its news and current affairs programming and entertainment content, the SABC has an influential role in shaping South African political debates and imaginings of post-apartheid nationhood. It is because of this wide influence that threats to the SABC's editorial independence and signs of its bias towards the ruling party have to be taken seriously (cf. Orgeret 2008, p. 627) The situation has been improving recently, as the SABC embarked on a process to improve its editorial standards and appointed a new board, in an attempt to reverse some of the damage done to the public broadcaster in the Zuma years (cf. Roper et al. 2019, p. 9). The SABC also faces increased commercial competition from other television channels available on terrestrial and digital platforms to South African viewers.

The commercial media landscape in South Africa is highly concentrated in the hands of a handful of big conglomerates, notably Naspers, with its news business Media24 serving as an umbrella for a wide range of newspapers, magazines and online news platforms and via its digital subscription service Multichoice, dominates the paid television market; Independent Media, which publishes a number of newspapers and magazines nationally; Caxton Publishers, which is an especially active participant in the local, commercial community newspaper publishing space, and Arena Holdings, which publishes some major newspaper titles and also owns broadcast channels. The Covid-19 pandemic has had a particularly devastating impact on the magazine landscape. The Associated Media Publishing group, publisher of several consumer magazine titles, had to close its doors in May 2020, while in the same month Caxton Publishers announced that it would withdraw from publishing magazines, with at least 10 titles facing closure. The small independent newspaper sector was also hit hard by the pandemic, as advertising dried up as a result of the government's lockdown — which prevented small business owners from operating - and the sharp economic downturn.

Although at the time of writing the future was still unclear, South Africa's news media looked set on concentrating even further in the aftermath of the pandemic, as smaller players struggled to survive without the resources of big companies to carry them through the crisis. 
News media have embraced digital publishing. Most newspapers and magazines have online versions, with some news publications-like Vrye Weekblad, Daily Maverick and GroundUp-existing exclusively online. News24, part of the Naspers conglomerate, is the leading online daily news provider. South Africa's internet penetration rate is fairly high, with $55 \%$ of the population having access to the Internet in 2020 (cf. Internetworldstats 2020). Social media usage has also seen a sharp growth in recent years. In 2020, 22 mio. South Africans used social media, an increase of 3.5 million (or 19\%) in the past year. Whatsapp is the major messenger app in the country (cf. Kemp 2020). Mobile phone penetration in the country is very high, with $176 \%$ of the population having a mobile connection in 2020 , a $3.1 \%$ year-on-year increase. This is an important figure, as $96 \%$ of all internet users access the internet through their mobile phones (cf. Kemp 2020).

The media is regulated by two overarching bodies, namely the Press Council of South Africa and the Broadcasting Complaints Commission of South Africa (BCCSA). These bodies have their own codes of conduct, and can impose fines (in the case of the BCCSA) or, in the case of the Press Council, demand apologies in the form of "space fines" (an apology of similar length and prominence as the offending article). The Press Council, especially, has been subject to much criticism during the first decades of democracy, as it was alleged to side with the media industry and did not impose strong enough sanctions. This criticism, the way this relates to political influence in the media sphere and the media's attempts to deflect such criticism, will be dealt with in more detail below.

\section{The impact of democratic transition on the media}

It has been noted above that while democratization is a useful approach to understand the political changes that South Africa has undergone since 1994, a teleological view of democratization should be avoided. This also applies to the media's role within this process. At first glance, a comparison between the South African media today, in a democracy where freedom of expression is guaranteed by the Constitution, with the situation under apartheid, when the media was hamstrung and repressed by the apartheid government, seems to lead to the obvious conclusion that democracy and a free and independent media go hand-in-hand. Although the situation is clearly much improved, and the South African media is now much freer to act as a robust watchdog of political power, the relationship between the media and government has often shown signs of strain. There are increasing examples of politicians' intolerance for media criticism, but also of political interference and attempts at capturing the media agenda for political gain. The intolerance for criticism can be seen to be especially directed at the print media, which continues to be associated with elite views and therefore an obvious target for attacks. Political interference, in turn, was most evident at the public broadcaster, the SABC, while the most egregious example of a misinformation campaign was the one orchestrated by the British public relations company Bell Pottinger, aimed at diverting attention away from corruption allegations against former president Jacob Zuma (cf. Wasserman 2017). These examples of renewed pressure on media freedom suggest that the media- 
democracy relationship should be seen as cyclical rather than a constant upwards trajectory towards an established, Western-style democracy. Moreover, the media's relationship towards broader society has also come in for criticism. The view that the media largely caters for a societal elite and that media agendas do not resonate with the poor, the youth and the marginalised, points to mitigated optimism about the South African media's ability to deepen democracy by widening participation in the mediated public sphere.

Under apartheid, the South African media's ability to report was significantly hampered by an array of repressive laws, including a prohibition on quoting 'banned persons' such as the liberation leader Nelson Mandela or even publishing their pictures. The mainstream, commercial media either displayed varied levels of support for the apartheid regime (in the case of the Afrikaans-language media) or provided a limited criticism of the regime's human rights abuses while benefiting from an association with mining capital that prevented them from a deeper engagement with the economic basis of apartheid. The South African Broadcasting Corporation (SABC) served as a state broadcaster during the apartheid years, while journalists and editors working for alternative, 'underground' anti-apartheid media were routinely harassed or imprisoned.

The advent of democracy in 1994 brought about radical changes in terms of the freedom afforded to South African media to do their work, but also in terms of the normative roles envisioned for the media in a young democracy. Not only was the granted unprecedented freedom in the 1996 Constitution as part of a wider recognition of freedom of expression, but a strong emphasis was placed on an ethical, independent but publicly accountable media. This vision of the media as having an indispensable democratic function which is inextricably linked to its ethical obligations towards society, is for instance expressed in the preamble to the code of the South African Press Council as follows: "(E)thical journalism is essential to realising the promise of democracy [...]. The press exists to serve society and that self-regulation by the press is enriched by public participation in a co-regulatory process." (Press Council of South Africa 2009)

Although the media has been able to operate freely and without fear of government interference since the advent of democracy, there has been a lack of consensus about what exactly the above democratic role would entail and how the media's ethical duties and public accountability should be enforced. Differences of opinion about whether the media should play a critical, 'watchdog' function or be more supportive of the new democratic government were especially intense during the first decade of democracy, when the media oscillated between support for the first democratic government and a critical, sceptical stance. The relationship between media and government was at times tense during the initial period following democratization, and meetings between the South African National Editors' Forum and government officials were held in an attempt to come to a mutual understanding about the media's role and government's expectations (see Wasserman and De Beer 2005 for a discussion of some of these early clashes). Underpinning these clashes are fundamentally different normative conceptions of what the media's role within a post-colonial, 'new' democracy, and its relationship to government, should be. 
In more recent years, new developments have raised renewed concerns about the relationship between the government and the media, in particular the increased political interference in the free flow of information. Two important issues stand out. The first is the passing of the Protection of State Information Bill by Parliament. Although it has not yet been signed into law, the so-called Secrecy Bill has been strongly opposed by civil society organisations as it is seen as having the potential to hamper the ability of journalists to access classified information and therefore undermine the media's democratic role to keep government accountable to the public (see Wasserman and Jacobs 2013 for a more detailed discussion).

Another important debate during the past decade has been the one around stronger regulation of the media. The self-regulatory regulatory system, especially as applied to the print and online news media by the Press Council of South Africa, has regularly been subjected to criticism from especially members of the ruling party, the African National Congress. This criticism came to a head during the tenure of former president Jacob Zuma, who has faced allegations of corruption and "state capture" and was forced to step down in February 2018, to be succeeded by the current president, Cyril Ramaphosa. The ANC first adopted a resolution to explore a statutory Media Appeals Tribunal (MAT) as an alternative to the appeals procedure in the system of press self-regulation at its 2007 National Conference, where Zuma was elected to the top leadership of the party. This resolution was developed into a party discussion paper in 2010, where it was argued that the self-regulatory system was inadequate to protect the privacy and dignity of individuals and was biased against the media. Although the MAT was never formally adopted, it did signal a growing intolerance among the ruling political elite for media criticism, and put into motion a process of revision of the self-regulatory system. A subsequent review of the Press Council's constitution and procedures, resulting in a system of voluntary co-regulation with greater input from citizens, seems to have put the ANC's demands for a MAT on hold. Attacks on the media however continued and intensified, as these have increasingly moved to the online space of social media. The most egregious example of these attacks has been the campaign run by the UK-based PR firm Bell Pottinger to discredit journalists who unmasked their corrupt relationship with then president Jacob Zuma. Bell Pottinger did this by creating a large number of fake Twitter accounts to counter allegations of a corrupt relationship between their clients, the Gupta family, and then president Jacob Zuma, by alledging that investigative journalists who exposed the corruption were acting in service of the forces of "white monopoly capital".

The relationship between the media and political power is one-albeit crucially important-dimension of South Africa's transition to democracy and social shifts that continue to occur in its wake. Another important dimension is the South African media's relationship with society more broadly speaking. This relationship, and the ways in which it has continued to shift since the advent of democracy, is seen to be reflected in the normative debates about the media's regulation, ethical frameworks and the levels of trust that the public have in the media. The relationship of the media to broader society has also been impacted upon by political-economic factors related to the transformation of the media sector and the socio-economic conditions in the country, foremost among these the continued economic inequalities that persist well 
into the post-apartheid era. These factors influenced the extent to which the South African media can be said to have become more representative of the wider society in the democratic era. In the following two subsections these two dimensions of the changing media landscape-the broader structural transformations as well as the impact of socio-economic inequality on audience trust and media relevance-will be discussed, before focusing on normative debates in the subsequent section.

\subsection{Political-economic and regulatory shifts}

In his critique of the literature of 'transitology', Sparks (2009) argues that despite the popular view that the transition from authoritarianism to democracy will necessarily result in a liberal-democratic political dispensation linked to a market economy, the South African example suggests that democratization does not automatically result in substantial economic transformation. (The inverse assumption, that marketization of an economy would necessarily create a demand for democratization, Sparks argues, is proven false by the case of China.)

From the outset, the political-economic transformation of the South African media was on the agenda of the incoming ANC government. Even before it was formally elected to power, the ANC started planning the ways by which to achieve its aim of a media that could better serve a democratic society. In 1992, shortly after its unbanning, the ANC published its Media Charter, in which it committed itself to redressing the historical imbalances in the media sphere. A priority goal was to ensure that previously marginalized communities gain greater access to the media. In order to achieve these aims, a number of policy and regulatory changes were made. These are listed by Fourie (2002, p. 27) as being the following:

The restructuring of the public broadcaster (SABC) Under apartheid, the SABC functioned largely as a state broadcaster with the intent of upholding the apartheid regime's ideology. This could be seen not only in its highly controlled news broadcasts, but also in the organisation of its channels to reflect the notion of linguistic and ethnic separation. In the democratic era, the broadcaster has been given a public mandate and reports to Parliament, to ensure public accountability. It however follows a hybrid public/commercial funding model, with a strong reliance on advertising revenue which undermines to a large extent its ability to act independent of commercial interests. The aim of the transformation of the SABC was to ensure that it serves the needs of a democratic citizenry. Normative debates also emerged in the SABC's restructuring process, with some in the new ruling party saw the broadcaster as crucial to a "nation-building" or "developmental" project that would assist rather than criticize governmental restructuring efforts (cf. Horwitz 2001, p. 330). Although structures were put in place to ensure its independence, these structures were gradually eroded through internal reorganisations and the growth of a managerial class at the SABC, including interventions in editorial matters. The broadcaster's finances are currently in a very poor state due to mismanagement and corruption spanning many years. Furthermore, political interference into editorial matters manifested again in the democratic era, especially during the Zuma era. 
Increased support for community media An important intervention in the postapartheid media landscape was the creation of a three-tier broadcasting system, consisting of a public broadcaster (as described above), the commercial broadcasters and community broadcasters. The restructuring of the broadcast sector after apartheid was in line with a three-tiered, mixed private-public-community media system built on principles of inclusivity and diversity (see Horwitz 2001, p. 328 for a discussion of these principles). The regulation and licensing of the latter tier was done in an attempt to provide a counterbalance to the dominance of commercial broadcasters. More than 100 community radio stations were licensed during the early democratic period in an attempt to "give disadvantaged black communities a voice as well as the opportunity to produce their own media, in their own languages" (Bosch 2017, p. 1). According to the Independent Broadcasting Authority Act (no. 4 of 1999), community radio stations had to comply with a number of requirements, for instance ensuring that programming is aimed at the particular community in question, reflects the language of their audience and devoting $20 \%$ of music broadcast to music of South African origin (cf. Bosch 2017, p. 60).

Another attempt to broaden the media's reach to underserved publics was made by strengthening the community media sector through the establishment of the Media Development and Diversity Agency. The agency's mandate was to support community print and broadcast media through grants, but the agency has also been struggling with lack of funding and allegations of mismanagement in recent years.

Facilitating the entry of black ownership into the media market Two major transactions in the area of the print media market took place in the 1990s which heralded a significant change in the ownership of the commercial media. These transactions involved Black empowerment consortiums (New Africa Investment Limited, or Nail and Johnnic Holdings) and brought some of the biggest newspaper titles under Black ownership. A large section of the English-language print media was subsequently bought by the Irish-owned Independent Group under Tony O'Reilly. The purchase of Independent from its Irish owners in 2013 by Sekunjalo brought the titles under black ownership again, but although this move was purported to be in the interest of transformation, it eventually became evident that the ideal of transformation was perverted by the new owner, Iqbal Survé, who interfered in editorial decisions to the extent that many black staff deserted the company and the group's newspapers lost their credibility (cf. Dasnois and Whitfield 2019). Transformation attempts in the commercial newspaper arena therefore had mixed success.

The improvement and extension of telecommunications As was the case with print and broadcast media, the telecommunications services in apartheid South Africa were also "fully ensconced within the apartheid political calculus" (Horwitz 2001, p. 179). The telecommunications service needed to be extended to black neighbourhoods and former black 'homelands' while steering a careful path between demands for cost rationalization and commercialization and the political resistance against privatization. Broadly speaking, telecommunications policy was developed to meet the imperative of serving a more inclusive, democratic society while fitting within the broader economic policy framework that required parastatals such 
as the telecommunications services to become sources of revenue (Horwitz 2001, p. 281). In the contemporary telecommunications era dominated by digital and mobile communications, some of the tensions between market forces and democratic imperatives of broadening access can still be seen in the demands that data be made more affordable. In 2019, South Africa's Competition Commission ordered that private telecommunications service providers lower the prices of data by around $50 \%$ or face prosecution, as South African data prices were found to be much higher than those in comparable developing economies, and affordable data is seen as an important resource for South African users who need to participate in a data-driven economy (cf. Dlulane 2019).

The establishment of regulatory bodies One of the most important policy changes that took place during the transition from apartheid to democracy was the establishment of regulatory bodies to oversee the implementation of the new set of normative expectations that democracy brought with it. What exactly the remit of these regulatory bodies should be, how they should operate and what their points of reference should be, has however been the cause for much debate and contestation which is still ongoing. The debates about policy and regulation can be seen as an indication that the democratization of the South African media should not be seen in terms of a simple teleologic chronology that ended with the formal establishment of a multi-party democracy in 1994 and the enshrinement of media freedom in the Constitution of 1996, but is an ongoing process of negotiation and contestation. Indeed, the debates about media policy and regulation often serve as proxy battles for competing ideas about the media's role in the new democracy. The regulatory bodies that came into being during the transition to democracy include the Independent Communications Authority (Icasa), which included the setting of quotas for local content on both public and commercial television and radio stations, the Broadcasting Complaints Commission of South Africa (BCCSA), which deals with complaints about alleged breaches of the broadcasting code of conduct, and the Press Council, which performs a similar role in the context of the print media. The latter regulatory body has in particular seen strong contestation with regards to its code, role and membership. We will return to a more detailed discussion of these normative debates below.

Although major shifts took place in the media landscape during the transition from apartheid to democracy, critics of the South African media's political economy have pointed out that these changes have not always succeeded in changing the media's preferential orientation towards elites into a more inclusive and diverse space. Colin Sparks (2009, p. 213), for instance, remarks on the changes in ownership and staffing of the South African media post-apartheid as a process of 'elite renewal', with one set of elites replacing another instead of a more substantial opening up of the sector. The content of especially the print media has also come under fire from critics (e.g. Friedman 2011) who have pointed out that the news agenda continues to favour issues of concern to a social and economic elite, disproportionately to matters that are of importance to the poor, black majority. The result, according to these critics, is that the post-apartheid public sphere remained bifurcated between those citizens that know how to access the media's agendas and create public debate around issues 
that concern them, and those that remain on the outside of those agendas (cf. Heller 2009). This situation pertains especially to the commercial media, which favours economic elites, but also has a bearing on the public media sector which relies for a large part on advertising (and therefore has an in-built bias towards economically empowered audiences) and community media, which—although mandated to serve communities across the socio-economic spectrum-often struggled to remain sustainable unless they resort to similar revenue models of the very commercial broadcasters that are their major competitors (Bosch 2017, p. 68).

While the appearance — about a decade into democracy — and meteoric rise (which slowed down in recent years) of tabloid newspapers managed to some extent to articulate the experiences of poor and marginalized citizens in ways that had not been the case before, these papers are owned by big commercial conglomerates and as such also have a profit motive rather than a true grassroots orientation (cf. Wasserman 2010).

This tension between the structural changes to the media landscape in the area of political economy and regulation, and the normative expectations that the democratic media should be more responsive to the voices of the poor and marginalized, have also characterized normative debates during the democratic period.

\subsection{Normative debates}

While the above-mentioned shifts and changes to the political-economic and regulatory landscape of the South African media during and after the transition to democracy were significant, some more substantive, normative questions emerged that continue to inform contemporary debates. The new, negotiated Constitution adopted in 1996 safeguarded the right to freedom of expression, alongside the right to human dignity. In the years to follow it became clear that these two rights were sometimes in tension. While the media have stood firm on the right to freedom of expression, especially in the light of increasing clashes and tensions with the government and the ruling party, critics have accused the media of not having contributed enough to the restoration of citizens' right to human dignity and the healing of South African society. This tension have been articulated in questions such as:

- What role should the South African media play in a young, African democracy?

- What responsibility, if any, does the South African media have to contribute to development and the iradication of social inequalities in South Africa?

- What, if any, are the limits to the freedom of speech enshrined in the Constitution, and how should that freedom be balanced with the Constitutional value of human dignity?

- How can the public's participation in media regulation be encouraged and ensured?

While these questions continue to be debated at home, and the media often served as a political playball for different parties or social and economic interests, the South African media increasingly had to reorientate itself not only in relation to local power struggles but also had to adapt to a rapidly changing global environment, which brought about daunting challenges for the media industries. The 
rise of digital technologies with the concomitant demands for the convergence production, publication and distribution platforms, the collapse of familiar advertisingbased business models, the increased possibilities for the public to participate in the creation, curation and distribution of media content, and the proliferation of independent and alternative media sites, also had a massive impact on the South African media's operations. Some sectors of the industry, especially newspapers, had to contend with steep circulation losses and severe staff cutbacks. The fact that the South African media also also re-entered the global arena after years of economic sanctions and political isolation, exacerbated this situation, as South African audiences could now choose from a range of competing global outlets. Local media companies were bought up by international interests and became involved in global geopolitics of the media- the Irish Independent media group bought and consolidated a number of English-language newspapers shortly after democratization, which were later bought back by the controversial South African businessman Iqbal Survé, partly funded by a Chinese consortium. Survé has been widely criticized for his role in eroding the editorial integrity of these papers and for his firing journalists who disagreed with him (cf. Dasnois and Whitfield 2019). South African media enterprises extended their reach into other parts of Africa and indeed the world, and hybrid forms of media emerged in the country as a result of the coming together of global formats and local content, of which mass-market tabloids aimed at a black, township-dwelling readership is a good example.

The normative questions mentioned above arise from the South African media's attempts to find its position amidst these various local, regional and global shifts and reconfigurations. Primary among these has been the South African media's attempts to come to grips with is democratic roles and responsibilities. As has been the case in other 'new democracies' such as those emerging in Central Europe after the end of the Cold War or in other African countries after the end of colonialism (see Murphy 2007 , p. 2), the opening up of a democratic public sphere, the intensified impact of globalization with the end of the country's isolation and the redefinition of the media's relation with civil society had profound implications for the way that the South African media conceived of its role in normative terms. As has been the case in other countries undergoing democratization, a key question has been whether the end of authoritarianism brought about complete transformation of society-including the media-or merely resulted in the repositioning of partnerships between elites (cf. Sparks 2008, 2009; Splichal 1992).

The media's attempts to reconfigure their normative position in the new democracy has from the outset been done under a great deal of pressure. The relationship between journalists and the African National Congress(ANC)-led government has been characterized by tensions throughout the post-apartheid era. In the initial years after the advent of democracy, the tensions and conflicts arose largely from differences of opinion with regards to the rules and responsibilities of the media in a new democracy, and debates about whether the monitorial, 'watchdog' role of the media as practiced in established democracies in the West should be preferred above the collaborative or developmental model that would see the media being less critical of the government and more supportive of its aims and goals. In the last decade, especially during the tenure of former President Jacob Zuma, this relationship deteri- 
orated as the ruling party became under intense scrutiny as allegations of widespread corruption and malfeasance. As journalists increased their monitoring of political power, so the intolerance on the part of the ruling party increased. In what was widely criticized as a way for government to increase their power over the free flow of information, a Protection of State Information Bill (POSIB, or "Secrecy Bill") was passed in 2011 by Parliament (however up to date not yet signed into law) amidst ongoing threats by ruling party to establish a statutory Media Appeals Tribunal (MAT), with harsher sanctions against offending journalists than the current self-regulatory system allows for. While the Secrecy Bill raised concerns about the limitations it could impose on whistle-blowers exposing corruption, and also make it more difficult for the media to report on it, the proposed Media Appeals Tribunal was seen as confirmation that the ruling party became increasingly sensitive to media reports of corruption and mismanagement. The Tribunal proposal was linked to growing criticism by the ruling party of the self-regulatory South African Press Council and Press Ombudsman. In their view, these self-regulatory systems were too soft on the media industry and did not impose harsh enough sanctions. These criticisms were largely allayed by a campaign by the Press Council in 2011 to solicit input from the public on how to improve its system of self-regulation. The outcome of this process was a revised Press Code and Constitution for the Press Council, which allowed for more, and more direct, public participation in these processes. Another process, the Press Freedom Commission, was established in the same year to investigate the self-regulatory process and to make recommendations to the media industry.

These two processes were concluded and resulted in the restructuring of the Press Council into a more participatory body with more members of the public sitting in the Appeals Council. Although this system can now more accurately be referred to as one of voluntary co-regulation rather than self-regulation, the ethics of the journalism industry remains under scrutiny and the regulatory processes continue to be contested. Almost a decade after the restructuring of the Press Council as described above, a new enquiry into media ethics and regulation was launched by the South African National Editors' Forum (SANEF) in 2019. Noting "a number of disturbing trends in our industry including the erosion of public trust, the decline of editorial independence due to a number of issues including the encroachment of media owners and shrinking newsrooms linked to large scale retrenchments" as well as the erosion of trust in journalism in the era of misinformation and "journalists sometimes backing certain political factions, which has muddied the waters by tainting the whole industry" (SANEF 2019). These trends prompted SANEF to establish an inquiry into media ethics by a commission headed by a retired judge. The aim of this inquiry is to 'investigate what went wrong with some of our journalism in recent years and how we can fix these gaps and loopholes so that trust and alliances between us and the public can be built' (SANEF 2019).

It should therefore be clear that more than two and a half decades into democracy, the South African media's normative frameworks as well as its regulatory processes continue to be contested and debated. This is an indication of the extent to which the media remains a proxy for larger debates about democratic society, participatory citizenship and freedom of expression. And while tensions between the media, government and corporate interests continue to bear on journalistic norms and practices, 
the robust discussions about these issues are an encouraging sign of the recognition of the media's importance in public life.

The South African case is a good example of how normative theories are linked to their social, political and historical contexts. The media ethics landscape in South Africa has been a terrain of much debate since the democratisation of the country. Procedural ethics, in the form of press codes and self-regulatory systems, have been set up to align with the new democratic values of transparency and accountability. However, in substantive terms, there is still much negotiation, contestation and disagreement about what the role of the media in post-apartheid society should look like, how media should contribute to the deepening of democracy and how media could contribute to the overcoming of continued marginalization of a large part of its citizenry.

\section{Conclusion}

The South African media has played an important political and social role in the two and a half decades since the end of apartheid. Benefiting from strong Constitutional guarantees of freedom of expression and a vibrant civil society, the South African media have contributed to a culture of democratic debate while playing a watchdog role to keep political power to account through investigative reporting into corruption and malfeasance. Despite these positive developments in the emerging democracy, the role of the South African media has also been contested. The media itself bears the characteristics of the continuing severe socio-economic inequalities in the rest of South African society, and have been accused of serving mostly an elite. Normative self-regulatory policy in the country has also been contested and has gone through several revisions in order to be more responsive to the needs of the developing South African society.

While the renewed attacks on media freedom and the intolerance for critique were rightly seen as worrying indications of the emergence of renewed authoritarian impulses, the resistance offered to these pressures are in themselves testament to a robust democratic public sphere and a strong civil society-an inheritance of the democratic anti-apartheid movements of the pre-1994 era. These conflicts also underscore the importance of viewing democratization not as a teleological, linear process, but as a cyclical one where progression towards greater freedoms can regress into authoritarian lapses, or where democratic forces compete with patrimonial networks. The South African example provides a good illustration of how the media is at the centre of these contestations, both as a reflection of wider societal dynamics and as a stakeholder in the new democracy itself.

\section{References}

Bosch, T. (2017). Broadcasting democracy: radio and identity in South Africa. Cape Town: HSRC Press. Dasnois, A., \& Whitfield, C. (2019). Paper tiger. Cape Town: Tafelberg.

Dlulane, B. (2019). SA data prices must be reduced-Competition Commission. https://ewn.co.za/2019/ 12/02/sa-data-prices-must-be-reduced-competition-commission. Accessed 11 Dec 2019. Eyewitness News 2, December. 
Fourie, P. (2002). Rethinking the role of the media in South Africa. Communicare, 21(1), 17-40.

Friedman, S. (2011). Whose freedom? South Africa's press, middle-class bias and the threat of control. Ecquid Novi: African Journalism Studies, 32(2), 106-121.

Heller, P. (2009). Democratic deepening in India and South Africa. Journal of Asian and African studies, 44(1), 123-149.

Horwitz, R. B. (2001). Communication and democratic reform in South Africa. Cambridge: University of Cambridge Press.

Internetworldstats (2020). Internet users statistics for Africa. https://www.internetworldstats.com/stats1. htm. Accessed 11 June 2020.

Kemp, S. (2020). Digital 2020: South Africa. https://datareportal.com/reports/digital-2020-south-africa. Accessed 18 May 2020.

MDDA (Media Development and Diversity Agency) (2020). About us. https://www.mdda.org.za/copy-ofabout-mdda. Accessed 18 May 2020.

Murphy, P. D. (2007). Negotiating democracy: media transformations in emerging democracies. Albany: SUNY Press.

Orgeret, K.S. (2008). From his master's voice and back again? Presidential inaugurations and South African television-the post-apartheid experience. African Affairs, 107, 611-629.

Press Council of South Africa (2009). Constitution of the press council of South Africa. https://www. presscouncil.org.za/pcsa_constitution/. Accessed 21 Nov 2019.

Roper, C., Newman, N., \& Schulz, A. (2019). Reuters Institute digital news report: South Africa supplementary report. https://reutersinstitute.politics.ox.ac.uk/sites/default/files/2019-06/South_Africa_ DNR_FINAL.pdf. Accessed 11 June 2020.

SANEF (South African National Editors' Forum) (2019). SANEF AGM takes critical decisions to support the media industry and to launch an inquiry into media ethics and credibility issues. https:// sanef.org.za/sanef-agm-takes-critical-decisions-to-support-the-media-industry-and-to-launch-aninquiry-into-media-ethics-and-credibility-issues/. Accessed 28 Feb 2020.

Sparks, C. (2008). Media systems in transition: Poland, Russia, China. Chinese Journal of Communication, 1(1), 7-24.

Sparks, C. (2009). South African media in transition. Journal of African Media Studies, 1(2), 195-220.

Splichal, S. (1992). Media privatization and democratization in Central-Eastern Europe. International Communication Gazette, 49(1/2), 3-22.

Stremlau, N., \& Iazzolino, G. (2017). Communications, power and governance in democratisation conflicts. MecoDEM working paper. http://www.mecodem.eu/wp-content/uploads/2017/04/StremlauIazzolino-2017_Communications-power-and-governance-in-democratisation-conflicts.pdf. Accessed 19 Nov 2019.

Vladisavljević, N. (2015). Media framing of political conflict: a review of the literature. MecoDEM working paper. http://www.mecodem.eu/wp-content/uploads/2015/05/Vladisavljevi\%C4\%87-2015_ Media-framing-of-political-conflict_-a-review-of-the-literature.pdf. Accessed 19 Nov 2019.

Voltmer, K. (2013). The media in transitional democracies. Cambridge: Polity.

Voltmer, K. (2019). Introduction: democratization conflicts as communicative contestations. In K. Voltmer, C. Christensen, I. Neverla, N. Stremlau, B. Thomass \& H. Wasserman (Eds.), Media, communication and the struggle for democratic change: case studies on contested transitions (pp. 1-31). Cham: Palgrave Macmillan.

Voltmer, K., Christensen, C., Neverla, I., Stremlau, N., Thomass, B., \& Wasserman, H. (Eds.). (2019). Media, communication and the struggle for democratic change: case studies on contested transitions (pp. 1-31). Cham: Palgrave Macmillan.

Wasserman, H. (2010). Tabloid journalism in South Africa: true story! Bloomington: Indiana University Press.

Wasserman, H. (2017). Fake news from Africa: panics, politics and paradigms. Journalism: Theory, Practice, Critique. https://doi.org/10.1177/1464884917746861. https://doi.org/10.1177/1464884917746861

Wasserman, H., \& De Beer, A.S. (2005). A fragile affair: an overview of the relationship between the media and state in post-apartheid South Africa. Journal of Mass Media Ethics, 20(2/3), 192-208.

Wasserman, H., \& Jacobs, S. (2013). Media, citizenship and social justice in South Africa. In U. Pillay, G. Hagg \& F. Nyamnjoh (Eds.), State of the nation 2012-2013 (pp. 333-354). Cape Town: HSRC.

H. Wasserman (D. Litt) is Professor of Media Studies and Director of the Centre for Film and Media Studies, University of Cape Town, South Africa. 